\title{
APPLICATION OF SOY PROTEIN ISOLATE IN THE FINING OF RED WINE
}

\section{APLICAÇÃO DE ISOLADO PROTEICO DE SOJA NA CLARIFICAÇÃO DE VINHO TINTO}

\author{
Evandro Ficagna $^{1 *}$, Angelo Gava ${ }^{1}$, Simone Bertazzo Rossato ${ }^{1}$, César Valmor Rombaldi ${ }^{2}$, Elessandra da Rosa \\ Zavareze $^{2}$
}

\author{
${ }^{1}$ Instituto Federal de Educação, Ciência e Tecnologia do Rio Grande do Sul, Campus Bento Gonçalves, Bento Gonçalves, 95700-206, Rio Grande \\ do Sul, Brazil. \\ ${ }^{2}$ Universidade Federal de Pelotas - UFPEL, Campus Universitário, Pelotas, 96010-900, Rio Grande do Sul, Brazil.
}

*Corresponding author: Tel: +55 543455 3221, E-mail: evandro.ficagna@bento.ifrs.edu.br.

(Received 26.03.2019. Accepted 13.07.2019)

\section{SUMMARY}

Soy protein isolate was evaluated as a potential fining agent as an alternative to the predominant protein commercial fining agents (ovalbumin, porcine gelatin, and pea protein isolate). Two red wines (cv. 'Merlot' and cv. 'Lambrusco Maestri') were finned, bottled, and analyzed for phenolic content, color, turbidity, and sensory profile. Independent of the protein used, fining promoted a reduction in a majority of the phenolic compound, a slight (but significant) reduction of chromatic properties, and a decrease in the turbidity of the wines. A decrease in astringency, persistence, bitterness, and wine body, as well as an increase in brightness, clarity, and acidity, was also observed in all treatments. The application of soy protein isolates yielded similar results to those obtained with other commercial fining agents, both in the physicochemical and the sensory measures, which favors its usage as an alternative to the traditional fining agents of animal-protein origin.

\section{RESUMO}

Avaliou-se o isolado proteico de soja como potencial agente clarificante, comparativamente aos principais clarificantes proteicos comerciais (ovoalbumina, gelatina suína e isolado proteico de ervilha). Dois vinhos tintos (cv. 'Merlot' e cv. 'Lambrusco Maestri'), foram clarificados, engarrafados e analisados quanto à composição fenólica, cor, turbidez e ao perfil sensorial. Independente da proteína utilizada, a clarificação promoveu redução na maioria dos compostos fenólicos avaliados, ligeira (mas significativa) diminuição das características cromáticas, e decréscimo na turbidez dos vinhos. Também houve redução da adstringência, da persistência, do amargor e do corpo/estrutura do vinho, sendo realçadas características como brilho, limpidez e a acidez, em todos os tratamentos. A aplicação do isolado proteico de soja proporcionou resultados similares àqueles obtidos com os demais clarificantes comerciais, tanto sob o aspecto físico-químico como sensorial, sendo uma alternativa técnica aos tradicionais clarificantes proteicos de origem animal.

Key words: vegetable protein, color, turbidity, sensory, alternative additive.

Palavras-chave: proteína vegetal, cor, turbidez, sensorial, aditivo alternativo.

\section{INTRODUCTION}

Many technical questions arise while making decisions on enological practices, such as the choice of grape variety, harvest time, maceration and fermentation types, and the lack or addition of winemaking inputs. Moreover, while they may be cultural, ideological, or purely commercial, there is an increase in the incorporation of new concepts in enology (Cargnello, 2009).
The fining of wines is a widely employed enological practice, even though a wide range of variations exists in the process (Tschiersch et al., 2010). The primary goal of fining is to promote the clarification of wine and to improve its stability. In red wines, fining agents are added to remove the phenolic substances, thereby avoiding colloidal precipitation and making the wine more clear and stable (Yokotsuka and Singleton, 1995; Marchal et al., 
2002). However, the modification of the colloidal matrix of wine to promote fining and stability can change the sensory characteristics, predominantly due to a reduction in the concentration of tannins (Maury et al., 2003).

Most of the widespread commercial protein fining agents for wine, such as egg albumin (ovalbumin) and gelatin, are of animal origin. However, with the discovery of the transmissible nature of Bovine Spongiform Encephalopathy (BSE) and concerns about the potential risk of allergies and food intolerance from products of animal origin, the search for a new protein source was initiated (Marchal et al., 2002; Maury et al., 2003; Jiménez-Martínez et al., 2017). As a result, several fining agents were studied and proposed as an alternative to traditional agents, for example, proteins of cereals, legumes, potatoes and grape seeds (Simonato et al., 2009; NoriegaDominguez et al., 2010; Gambuti et al., 2012; Simonato et al., 2013; Vincenzi et al., 2013; JiménezMartínez et al., 2017; Togores, 2018; Vernhet, 2019).

Granato et al. (2018) evaluated in recent work that vegetable proteins are as effective as proteins of animal origin in the fining of red wines. Moreover, previous studies have reported that compared to gelatin, plant protein isolates are more efficient in the removal of phenolic compounds, as they can remove oxidized tannins, and promote a reduction of bitterness and astringency of the red wine (Aziz et al., 2017a). Therefore, seeks out alternate plant-based fining agents, derived from rich sources of protein, and are easily obtainable, preferably with low cost, be healthy and safe for consumers, and promote fining without negatively affecting wine quality.

The soy protein isolates are widely known and characterized and contain, in their final composition, $7 \mathrm{~S}$ ( $\beta$ conglycinin) and 11S (glycinin) protein fractions (Hermansson, 1978; Kinsella et al., 1985). Because these fractions possess good solubility and a positive charge at the $\mathrm{pH}$ typically found in red wines (3.2 to 3.8), they are thought to have the capacity to act as a fining agent.

The use of plant-derived proteins as wine fining agents can be a great alternative, ensuring food safety, not having the risk of BSE and other possible allergic reactions that the consumer may suffer from proteins of animal origin (Bindon and Smith, 2013). In addition, the use of vegetable proteins does not require the labeling of this additive, thus, avoiding the limitation of the marketing of wine to specific consumer segments, as well as avoiding an additional analytical cost (Rolland et al., 2006). Based on the previous reports, the present work aimed to analyze the efficiency of pea and soy isolates as possible fining agents.

Despite several works comparing fining agents, so far, there has been no published data that evaluated the effect of fining agents on the sensorial and physicochemical characteristics in two red wines. In addition, there lack enough data comparing various traditional and alternative agents, allowing a broader study on their effect on red wine. Therefore, a comparative study was performed; the trials were conducted in a manner to simulate industrial procedures, using commercial preparations of egg albumin, porcine gelatin, pea protein isolate, and soy protein isolate (non-commercial) on red wines of cv. 'Lambrusco Maestri' and cv. 'Merlot'. As the essential requirement of a fining agent is to diminish astringency and preserve the chromatic characteristics of wine, the objective of this study was to evaluate the turbidity, color, phenolic composition, and the sensory changes in the treated wine.

\section{MATERIAL AND METHODS}

\section{Wine}

For the experiment, two red wines were vinified with grapes from the 2012 vintage, in the Serra Gaucha (Brazil). The winemaking process for both cultivars, started with a homogenous volume of $200 \mathrm{~L}$ of must, prepared following destemming, crushing, enzyme treatment (commercial pectinase $20 \mathrm{mg} / \mathrm{L}$ ), addition of sulphite $(50 \mathrm{mg} / \mathrm{L})$, yeast $(250 \mathrm{mg} / \mathrm{L})$ and supplementation with nutrient $(250 \mathrm{mg} / \mathrm{L})$, maceration (seven days), racking, and additional sulphite (adjusted with $30 \mathrm{mg} / \mathrm{L}$ free $\mathrm{SO}_{2}$ ) addition after spontaneous malolactic fermentation.

The wine of 'Lambrusco Maestri' (L. Maestri) was chosen because of its deep color, high acidity (Bowman, 2018), and polyphenolic content, and as the wine often needs to be treated with fining agents such as albumin and gelatin to diminish the content of astringent tannins. The 'Merlot' wine represents the most significant portion of wine Vitis vinifera processed in Brazil (Rizzon and Miele, 2003; Machado et al., 2017).

The physicochemical characteristics of the wines used in the experiment are shown in Table I. The alcoholic strength $(\mathrm{mL} / \mathrm{L})$ of wines was determined using an enochemical distilling unit (Gibertini, Milan, Italy). Determination of density, total and volatile acidity, total, and free $\mathrm{SO}_{2}$ were performed according to OIV methods (OIV, 2009). The determination of sugar content $(\mathrm{g} / \mathrm{L})$ was performed based on the methodology of Lane-Eynon (Instrução Normativa $n^{\circ}$ 
24, 2005). The $\mathrm{pH}$ determination in the wines was performed with an MPA210 benchtop $\mathrm{pH}$ meter (Tecnopon, Brazil) according to Brazilian legislation (Instrução Normativa $\left.{ }^{\circ} 24,2005\right)$. The analyses were performed one month after the malolactic fermentation.

\section{TABLE I}

Analytical parameters of the red wines before fining

Parâmetros analíticos dos vinhos tintos antes da clarificação

\begin{tabular}{|c|c|c|}
\hline Parameter $^{\text {a }}$ & L. Maestri & Merlot \\
\hline Density (g/L) & 995 & 994 \\
\hline Alcohol content (mL/L) & 123 & 118 \\
\hline Sugar content $(\mathrm{g} / \mathrm{L})$ & 1.9 & 1.6 \\
\hline Volatile acidity ( $\mathrm{g} / \mathrm{L}$ acetic acid) & 0.4 & 0.5 \\
\hline Total acidity (g/L tartaric acid) & 5.5 & 4.9 \\
\hline $\mathrm{pH}$ & 3.42 & 3.39 \\
\hline Total $\mathrm{SO}_{2}(\mathrm{mg} / \mathrm{L})$ & 97.2 & 115.2 \\
\hline Free $\mathrm{SO}_{2}(\mathrm{mg} / \mathrm{L})$ & 36.8 & 31.4 \\
\hline Turbidity (NTU $\left.{ }^{b}\right)$ & 73.0 & 29.0 \\
\hline $420 \mathrm{~nm}$ & 4.67 & 3.78 \\
\hline $520 \mathrm{~nm}$ & 7.51 & 7.02 \\
\hline $620 \mathrm{~nm}$ & 1.67 & 1.16 \\
\hline Color intensity & 13.85 & 11.96 \\
\hline Total Tannins (mg/L) & 3.91 & 2.37 \\
\hline Total phenolic index $(280 \mathrm{~nm})$ & 85.0 & 58.4 \\
\hline Total anthocyanin $(\mathrm{mg} / \mathrm{L})$ & 2834.9 & 2423.4 \\
\hline Monomeric flavan-3-ols (mg/L) & 13.23 & 11.22 \\
\hline Oligomeric flavan-3-ols (mg/L) & 74.05 & 71.09 \\
\hline Polymeric flavan-3-ols (mg/L) & 310.19 & 281.89 \\
\hline Total flavan-3-ols (mg/L) & 397.47 & 374.20 \\
\hline
\end{tabular}

\section{Fining agents}

For fining, the following proteins were tested: egg albumin (AEB Group, San Polo, Italy), porcine gelatin (Esseco, San Martino, Italy), pea protein isolate (Enologica Vason, Verona, Italy), and soy protein isolate (SPI), which was extracted according to the method described by Wally-Vallim et al. (2014) and provided by Bremil - Industry Food Products, Rio Grande do Sul, Brazil. A dose of 0.20 $\mathrm{g} / \mathrm{L}$ was utilized for all proteins because it represents the maximum recommended dose for commercial pea protein and is close to the maximum value normally used for gelatin and albumin (Marchal et al., 2002; Tschiersch et al., 2010).

\section{Fining experiments}

The protein applications were performed after malolactic fermentation, by adding a total of $50 \mathrm{mg} \mathrm{\textrm {L } ^ { - }}$ ${ }^{1}$ total sulfur dioxide $\left(30 \mathrm{mg} / \mathrm{L}\right.$ final free $\left.\mathrm{SO}_{2}\right)$ into a volume of $4.6 \mathrm{~L}$ of wine. The protein solution fining agent $(10 \% \mathrm{w} / \mathrm{v}$ in distilled water) was introduced using a centrifugal pump with a capacity of $280 \mathrm{~L} / \mathrm{h}$ to promote its homogeneous incorporation into the wine. The same procedure was performed for the control wine that received no fining agent but received the same volume of water used for the dilution of all fining agent. After the incorporation of the agent, $4.6 \mathrm{~L}$ of the wine was packaged in glass containers and kept at a controlled temperature of 17 ${ }^{\circ} \mathrm{C}$ for seven days. The stabilized wine was separated from the precipitate by siphoning and was poured in $0.75 \mathrm{~L}$ bottles for analysis. All analyses were performed two months after bottling.

\section{Polyphenols quantification}

The total amount of tannins in the wines was determined based on the method described by Ribéreau-Gayon and Stonestreet (1966), using the principle of acid hydrolysis. The Total Polyphenol Index (TPI) was obtained by reading the optical density at $280 \mathrm{~nm}$ (Ribéreau-Gayon, 1970). The anthocyanin content was determined by an adaptation of the bisulfite method, according to the procedure previously described by Somers and Evans (1977). The flavan-3-ol fractions were obtained by preparatory $\mathrm{C} 18 \mathrm{Sep}-\mathrm{Pak}$ separation into three major fractions (monomeric, oligomeric and polymeric), following the method proposed by Sun et al. (1998), fractionation of neutral phenolic compounds was carried out using a C18 Sep-Pak cartridge (Waters Associates, Philadelphia, USA) according to Oszmianski et al. (1988), Mayén et al. (1995), and Gil-Muñoz et al. (1999). The neutral polyphenols retained in the cartridge were eluted using $16 \%$ acetonitrile at a $\mathrm{pH}$ of 2.0 to collect flavan-3-ol derivatives.

\section{Color and turbidity analysis}

The color indices were determined by a direct absorbance reading $(420 \mathrm{~nm}, 520 \mathrm{~nm}, 620 \mathrm{~nm})$ using a spectrophotometer, model T92+ (PG Instruments, Lutterworth, United Kingdom) having a quartz cuvette of $1 \mathrm{~mm}$ optical path. The color intensity was represented as the sum of the readings obtained at 420 $\mathrm{nm}, 520 \mathrm{~nm}$, and $620 \mathrm{~nm}$. All values were expressed for an optical path of $10 \mathrm{~mm}$ (Zamora, 2003). The turbidity of the wine was directly measured in a nephelometric turbidimeter (model AP2000, Brand PoliControl, Diadema, Brazil) that was previously calibrated with standard solutions of formazine. 
Turbidity was expressed in NTU (Nephelometric Turbidity Units).

\section{Sensory analysis}

A quantitative descriptive sensory analysis was performed on the premises of IFRS-Campus Bento Gonçalves, four months after bottling. The panel (with extensive wine tasting experience) consisted of 15 active winemakers from the Serra Gaucha region, all with at least five years of experience. The judges were provided with training, to adapt, and to record on an unstructured scale $(9 \mathrm{~cm})$ and with the sensory terms (17 attributes) used in the evaluation. These procedures were based on models described by Jackson (2002), Kemp et al. (2009), and Dutcosky (2011). An initial group of 10 panellists was selected, and the evaluation of the wines took place in two sessions (two different days), where 10 samples (five treatments in duplicate) were evaluated per session. The use of two sessions (one kind of wine per day) allowed a better evaluation of the parameters, avoiding the saturation of tasters at the time of evaluation. Samples were served in ISO approved wineglasses labeled with 3-digit random codes in random order and varied for each judge. The order of presentation of samples within each session was also randomized.

\section{Experimental design and statistical analysis}

A factorial experiment was arranged in a split-plot, and consisted of the combination of two different wines (plots) from the 2012 vintage ('Merlot' and 'Lambrusco Maestri') and five treatments: a control (no added fining agent) and four proteins designated as fining agent, two of animal origin (egg albumin and porcine gelatin) and two proteins isolated from vegetables (soy and pea). The experiments were carried out in triplicates. The physicochemical data were statistically evaluated by analysis of variance ( $\mathrm{p}$ $<0.01$ and $\mathrm{p}<0.05$ ), using the F-test (Fisher), and subjected to comparison by Tukey test $(\mathrm{p}<0.05)$.

For the quantitative descriptive sensory analysis, the experiment was arranged in split-plots, but in randomized blocks (evaluators) with two replications. All results were subjected to analysis of variance ( $p$ $<0.01$ and $p<0.05$ ), using the F-test (Fisher), followed by Tukey test $(\mathrm{p}<0.05)$.

The significance level for the principal component analysis (PCA) was set at $p<0.05$, and the statistical software Paleontological Statistics (PAST, version 3.2 , Oslo, Norway) was used for analysis (Hammer et al., 2001).

\section{RESULTS AND DISCUSSION}

\section{Phenolic composition of wines}

In general, all the fining agents studied caused a reduction in the phenolic content of the wines. However, except for the total tannin content and the total polyphenol index (TPI) (Figure 1), for which, no effect was observed, the results depend on the interaction between the wine type and the fining agent. Some authors have suggested that the high capacity of some protein agents for eliminating tannins could be due to their hydrophobic interactions (Cosme et al., 2009; Granato et al., 2014).

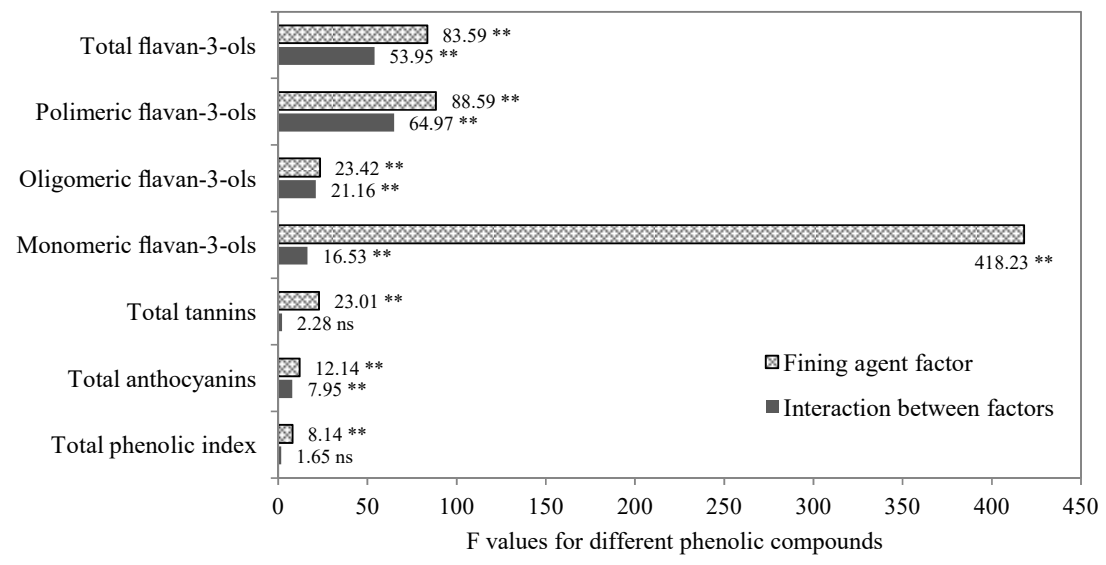

Figure 1. F values for fining agent factor and the interaction between wine and fining agent factors obtained in the analysis of phenolic compounds. ns - not significant; *significantly different $(\mathrm{p}<0.05)$; ** very significantly different $(\mathrm{p}<0.01)$.

Valores de F para o fator cola e a interação entre os fatores vinho e clarificante obtidos na análise de compostos fenólicos. ns - não significativo; * diferença significativa $(p<0.05)$; ** diferença muito significativa $(p<0.01)$. 
All proteins promoted a reduction in the levels of the phenolic compounds (Figure 2). These results were expected since fining proteins such as ovalbumin and collagen can complex with phenolic compounds (Robichaud and Noble, 1990; Cheynier et al., 2000; Brossaud et al., 2001).

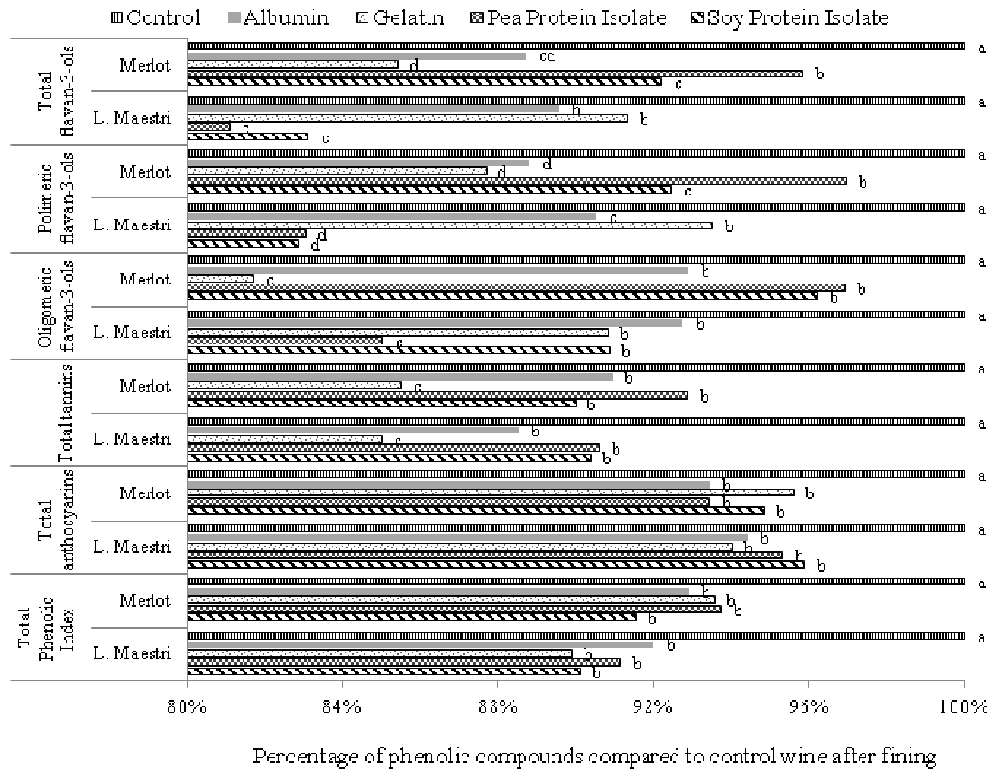

Figure 2. Phenolic compounds content depending on the application of protein fractions (egg albumin, porcine gelatin, pea protein isolate and soy protein isolate) in 'Lambrusco Maestri' and 'Merlot' wines. For each fining protein values followed by different letters are significantly different ( $\mathrm{p}<0.05$, Tukey’s test).

Conteúdo de compostos fenólicos conforme aplicação de frações de proteína (albumina de ovo, gelatina de suíno, isolado de proteina de ervilha e isolado de proteina de soja) em vinhos 'Lambrusco Maestri' e 'Merlot'. Para cada clarificante proteico, valores seguidos por letras diferentes são significativamente diferentes ( $p<0.05$, teste de Tukey).

In this study, the most notable interference occurred with the levels of monomeric flavan-3-ols (Table II). The results obtained are in agreement with those of previous experiments using model wine (Granato et al., 2010), 'Catalanesca' white wine (Granato et al.,
2014), 'Cabernet Sauvignon' press wine (Aziz et al., 2017a), 'Aglianico' red wine (Granato et al., 2018), and 'Monastrell' red wines (Jiménez-Martínez et al., 2019).

\section{TABLE II}

Monomeric flavan-3-ols content (mg/L) and percentage of decrease

Teor em flavan-3-ol monoméricos $(\mathrm{mg} / \mathrm{L})$ e percentagem de decréscimo

\begin{tabular}{|c|c|c|c|c|c|c|}
\hline \multirow[b]{2}{*}{ Fining agent } & \multicolumn{2}{|c|}{ L. Maestri } & \multicolumn{2}{|c|}{ Merlot } & \multicolumn{2}{|c|}{ Mean } \\
\hline & Value & Reduction (\%) & Value & Reduction (\%) & Value & Reduction (\%) \\
\hline Control & $13.23 \pm 0.45 \mathrm{aA}$ & & $11.22 \pm 0.05 \mathrm{bA}$ & & $12.23 \pm 0.79 \mathrm{~A}$ & \\
\hline Albumin & $5.68 \pm 0.35 \mathrm{aD}$ & $57 \%$ & $5.59 \pm 0.29 \mathrm{aC}$ & $50 \%$ & $5.63 \pm 0.19 \mathrm{D}$ & $54 \%$ \\
\hline Gelatin & $6.6 \pm 0.09 \mathrm{aC}$ & $50 \%$ & $6.75 \pm 0.28 \mathrm{aB}$ & $40 \%$ & $6.67 \pm 0.14 \mathrm{BC}$ & $45 \%$ \\
\hline PPI & $7.6 \pm 0.59 \mathrm{aB}$ & $43 \%$ & $6.74 \pm 0.19 \mathrm{bB}$ & $40 \%$ & $7.17 \pm 0.43 \mathrm{~B}$ & $41 \%$ \\
\hline SPI & $6.05 \pm 0.83 \mathrm{aCD}$ & $54 \%$ & $6.74 \pm 0.24 \mathrm{aB}$ & $40 \%$ & $6.39 \pm 0.47 \mathrm{C}$ & $47 \%$ \\
\hline Mean & $7.83 \pm 1.29 \mathrm{a}$ & & $7.41 \pm 0.92 \mathrm{a}$ & & $7.62 \pm 0.79$ & \\
\hline
\end{tabular}


There was an approximated $50 \%$ reduction of these compounds, and they contribute to the browning more intensely than other phenolics (Lee and Jaworski, 1988), and there is strong evidence of epicatechin being the most relevant browning agent among redoxactive polyphenols (Sioumis et al., 2006). As for the oligomeric flavan-3-ols, the pea protein was found to reduce their levels in the two evaluated wines, while the IPS did not differ from the animal proteins in the two wines. Granato et al. (2018) observed the opposite behavior in the clarification of a young red wine, where the IPS reduced more oligomeric flavan3-ols than IPE. This finding is important because the molecular size of the polyphenolic compounds present in wine affects its bitterness and astringency (Peleg et al., 1999).

In all cases, the addition of fining agents caused a decrease in total tannins. The reduction promoted by IPS was similar to animal protein $(10 \%$ in both wines), while the most significant decrease was obtained by PPI (15\%). In a study by JiménezMartínez et al. (2017) with clarification of red wine, IPE promoted greater reduction $(64 \%)$ of tannins when compared to two porcine origin gelatins, one mannoprotein-rich yeast autolyzed product, and pomace cell wall material.

Concerning the total anthocyanin content for both wines, the reduction was similar in all treatments, presenting only significant difference compared to the control wine. Similar results were reported by Jiménez-Martínez et al. (2019), where an evaluation in 'Monastrell' and 'Merlot' wines did not show a statistical difference for the total anthocyanins when treated with gelatin, albumin, or plant protein. In another study, gelatin presented a greater reduction of anthocyanins compared to the pea protein isolate (Aziz et al., 2017a).

Regarding the soy protein isolate, the trend of responses was similar to that of the other tested protein fractions, which is an important contribution, given the ease of obtaining this product. The wine to be finned influences the protein and its effect on the reduction of phenolic compounds. The action of SPI in fining is similar to the animal proteins, such as for the monomeric and oligomeric flavan-3-ols ('Lambrusco Maestri' wine), and is similar to pea protein isolate, as in the case of the polymeric flavan3-ols ('L. Maestri wine'). However, for the 'Merlot' wine, this pattern was not observed, reinforcing that the optimal fining protein might vary depending on the wine.

\section{Wine color}

Changes in the red wine color related to the fining treatments were analyzed by UV/V spectrophotometry at 420,520, and $620 \mathrm{~nm}$. For all the color parameters evaluated, no significant differences were observed between the four fining agents tested, even though they differed from the control wine. In a previous study, the fining of 'Raboso' red wine caused the reduction in red color $(520 \mathrm{~nm})$, and similar results were obtained using gelatin, albumin or pea protein as fining agents (Gazzola et al., 2017). In another study by JiménezMartínez et al. (2019) the color intensity obtained after fining of 'Monastrell' and 'Merlot' red wines with albumin, gelatin or plant protein did not show significant differences but were smaller than the control wine.

All treatments using the fining agent proteins presented a reduction in chromatic characteristics (Figure 3). There was a decrease in absorbance at 420,520 , and $620 \mathrm{~nm}$, representing yellow, red, and blue colors, respectively. A similar result was reported by Iturmendi et al. (2010), Cosme et al. (2012), Granato et al. (2018), and Kang et al. (2018), who studied the fining by vegetable protein from different sources. The SPI exhibited similar behavior to other commercial protein fining agents.

The reduction of color intensity is an expected result of fining treatments (Cosme et al., 2007; Gambuti et al., 2012). The anthocyanin content as well as the molecules that interact with anthocyanins, such as the tannins (Boulton, 2001), were reduced by the addition of fining proteins; the reduction of color intensity can be justified by this phenomenon, as reported by Harrison (2018). In this context, SPI was similar to other protein agents. Aziz et al. (2017b) did not find significant differences for the color intensity while fining with polyvinylpolypyrrolidone, gelatin, or pea protein isolate on 'Cabernet Sauvignon' wine. González-Neves et al. (2014) found that anthocyanin content was slightly reduced by the use of albumin and egg gelatin, and was not affected by the use of vegetable proteins (gluten proteins) in most of the red wines of 'Tannat' evaluated in the study. A similar behavior concerning the decrease in color intensity compared to the control wines was observed in the present study. 


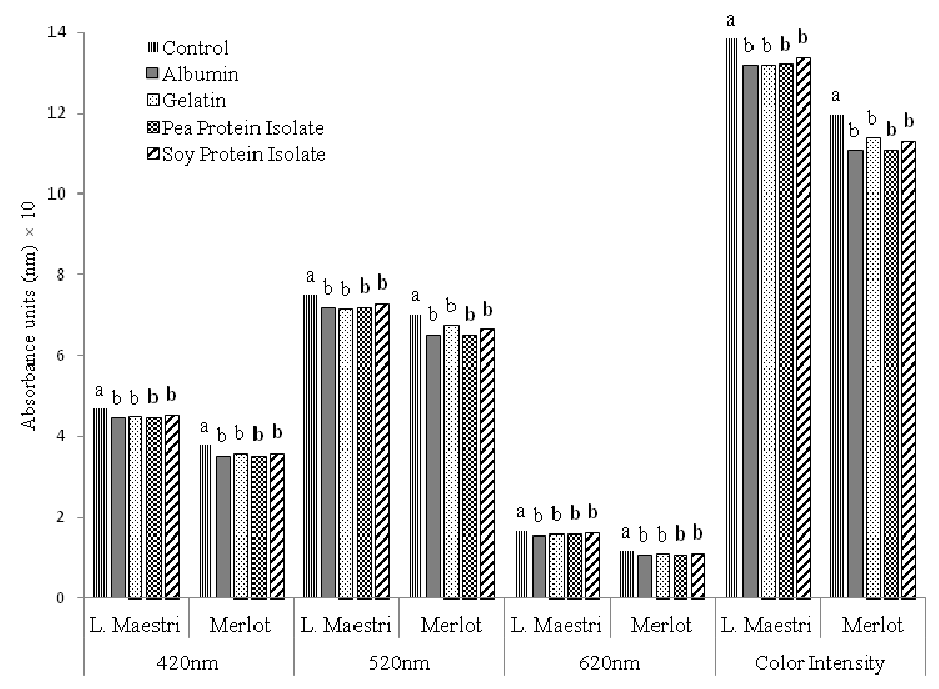

Figure 3. Chromatic characteristics of 'Lambrusco Maestri' and 'Merlot' wines treated with egg albumin, porcine gelatin, pea protein isolate and soy protein isolate. For each fining protein values followed by different letters are significantly different ( $\mathrm{p}<0.05$, Tukey’s test).

Características cromáticas dos vinhos 'Lambrusco Maestri' e 'Merlot' tratados com albumina de ovo, gelatina suína, isolado proteico de ervilha e isolado proteico de soja. Para cada clarificante proteico, valores seguidos por letras diferentes são significativamente diferentes ( $p<0.05$, teste de Tukey).

\section{Turbidity}

After seven days, all treated wines had turbidity ranging between 1.4 and $18.2 \mathrm{NTU}$; similar values to those reported by Granato et al. (2018). The turbidity was significantly reduced by the use of fining proteins, and there was no significant difference between the responses generated by SPI and PPI (Table III). Furthermore, the animal proteins promoted a greater reduction than the proteins of vegetable origin.

\section{TABLE III}

Turbidity (NTU) and percentage of turbidity decrease in the wines after treatments

Turbidez (NTU) e percentagem de diminuição da turbidez nos vinhos após os tratamentos

\begin{tabular}{ccccccc}
\hline & \multicolumn{2}{c}{ L. Maestri } & \multicolumn{2}{c}{ Merlot } & \multicolumn{2}{c}{ Mean } \\
Fining agent & Value & Reduction (\%) & Value & Reduction (\%) & Value & Reduction (\%) \\
\hline Control & $69 \pm 1.2$ & & $26.5 \pm 1.0$ & & $47.7 \pm 9.5 \mathrm{~A}$ & \\
Albumin & $14.1 \pm 1.4$ & $79 \%$ & $1.4 \pm 0.5$ & $95 \%$ & $7.8 \pm 2.9 \mathrm{C}$ & $84 \%$ \\
Gelatin & $14.9 \pm 1.4$ & $78 \%$ & $2.3 \pm 1.0$ & $91 \%$ & $8.6 \pm 2.9 \mathrm{C}$ & $82 \%$ \\
PPI & $17.5 \pm 0.9$ & $75 \%$ & $5.1 \pm 0.3$ & $81 \%$ & $11.3 \pm 2.8 \mathrm{~B}$ & $76 \%$ \\
SPI & $18.2 \pm 0.5$ & $74 \%$ & $5.7 \pm 0.7$ & $79 \%$ & $11.9 \pm 2.8 \mathrm{~B}$ & $75 \%$ \\
Mean & $26.7 \pm 5.7 \mathrm{a}$ & & $8.2 \pm 2.5 \mathrm{~b}$ & & $17.5 \pm 3.5$ & \\
\hline
\end{tabular}

Values with different capital letters in the same column (fining agent) and different small letters in the same row (wines) are statistically different Tukey's test $(\mathrm{p}<0.05)$. Mean values \pm standard deviation. PPI: pea protein isolate. SPI: soy protein isolate.

This effect on reduction was observed in both wines, indicating that for turbidity, there was no interaction between the factors and the wine proteins. The reduction promoted by animal proteins (albumin and gelatin) was $84 \%$ and $82 \%$, respectively, while the vegetable protein promoted a $76 \%$ and $75 \%$ reduction for the PPI and SPI, respectively. These values are similar to those found by Granato (2010).

For the 'L. Maestri' wine, the results presented minor differences between the plant and animal proteins, 
with a reduction of $74 \%$ (SPI) up to $79 \%$ (albumin), while for 'Merlot' wine the reduction results were between $79 \%$ (SPI) up to $95 \%$ (albumin). In the clarification of 'Raboso' red wine, Gazzola et al. (2017) observed that the most effective fining agent was egg albumin, while the pea proteins could not clarify the wine tested. Granato et al. (2018) observed lower turbidity values for fining with pea and soy protein isolate compared to gelatin application, after seven days of the fining in red wine.

\section{Sensory analysis}

The treatments (fining agent) and the interaction between factors (wine type and the fining agent) showed significant differences for most of the properties evaluated (Figure 4).
F-values for the interaction between factors (wine and the fining agent) were significant $(\mathrm{p}<0.01)$ for 10 of the 17 attributes, indicating the influence of the characteristics of the wine on the sensory effects of fining using different proteins. Of the 17 sensory characteristics evaluated, 12 showed significant Fvalues for the fining agent factor, indicating that the astringency and bitterness attributes, as well as the visual properties and olfactory intensity, were the most affected by protein fining agents. A handful of previous studies have reported similar results on the interaction between the fining agent and the wine type (Sims et al., 1995; Sarni-Manchado et al., 1999; Gómez-Plaza et al., 2000; Maury et al., 2001; Bonerz et al., 2004; Karamanidou et al., 2011; Vincenzi et al., 2013; Granato et al., 2018; Kang et al., 2018).

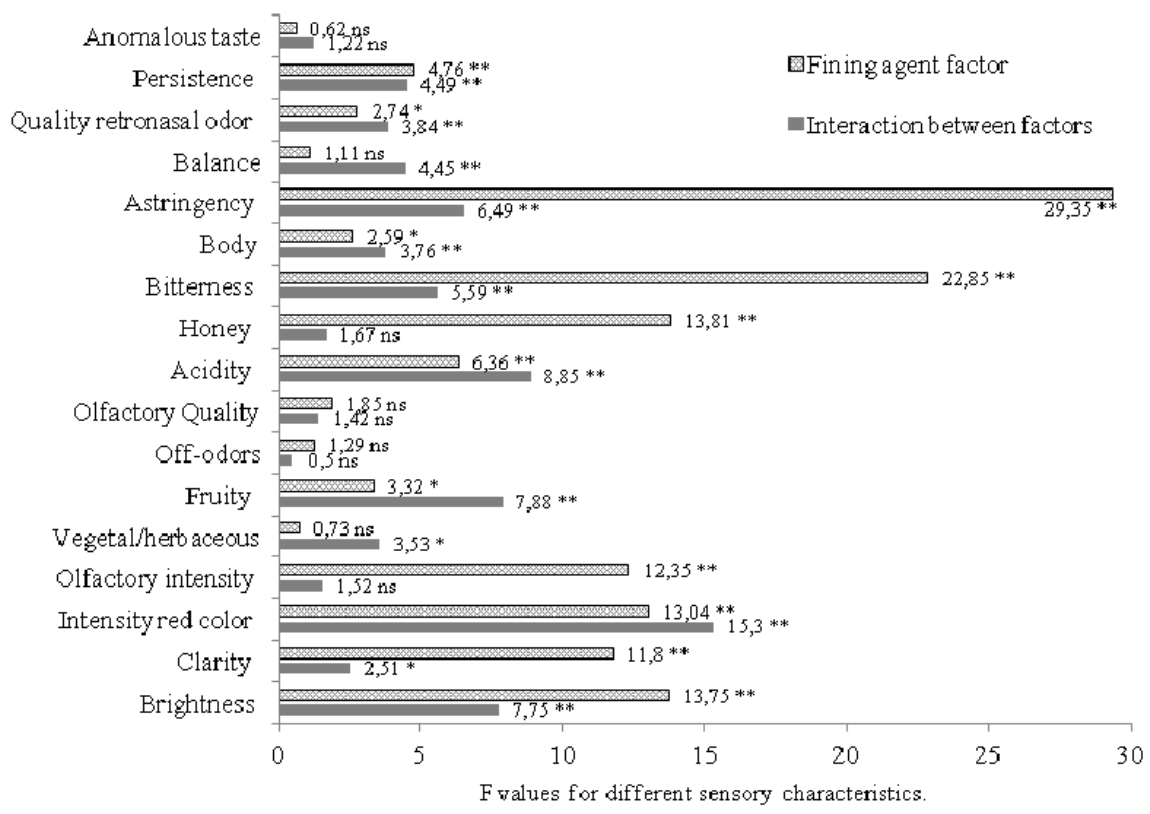

Figure 4. $\mathrm{F}$ values for fining agent factor and the interaction between wine and fining agent factors obtained in sensory evaluation by descritive quantitative analysis. ns - not significant; *significantly different $(\mathrm{p}<0.05) ; * *$ very significantly different $(\mathrm{p}<0.01)$.

Valores de F para o fator cola e a interação entre os fatores vinho e clarificante obtidos na avaliação sensorial por análise quantitativa descritiva. $n s-n \tilde{a} o$ significativo; * diferença significativa $(p<0.05)$; ** diferença muito significativa $(p<0.01)$.

The fining with SPI did not provide negative sensory changes; in fact, its effects were close to other commercial proteins evaluated. In 'L. Maestri' wine, good results were observed with SPI, compared to PPI, regarding the brightness and intensity of the red color (Figure 5). For the sensorial profiles of fine wines (Figures 6a and 6b), only the characteristics that showed statistical differences $(p<0.05)$ were presented.
The SPI decreased the bitterness and astringency, similarly to other commercial fining agents, showing no statistical differences $(p>0.5)$ between the types of fining agents studied. These results corroborated with Kang et al. (2018), who observed that the application of gelatin, pea protein isolate, and soy protein isolate did not present statistical differences in the reduction of astringency. Gazzola et al. (2017) also observed similar results in the reduction of astringency using 
albumin, soy protein isolate, and grape seed extract for red wine. However, both studies found no reduction in bitterness with these fining agents.

The reduction of bitterness and astringency is essential, as it is a requirement for a protein fining agent.The effect of fining proteins in reducing these characteristics is attributed to the interaction of the proteins with phenolic compounds, especially tannins, which are the main components responsible for astringency (Luck et al., 1994; Soares et al., 2017). It is previously reported that low molecular weight phenolic compounds, such as monomeric and oligomeric flavan-3-ols, might influence the bitterness of wines (Hufnagel and Hofmann, 2008; Sáenz-Navajas et al., 2010).

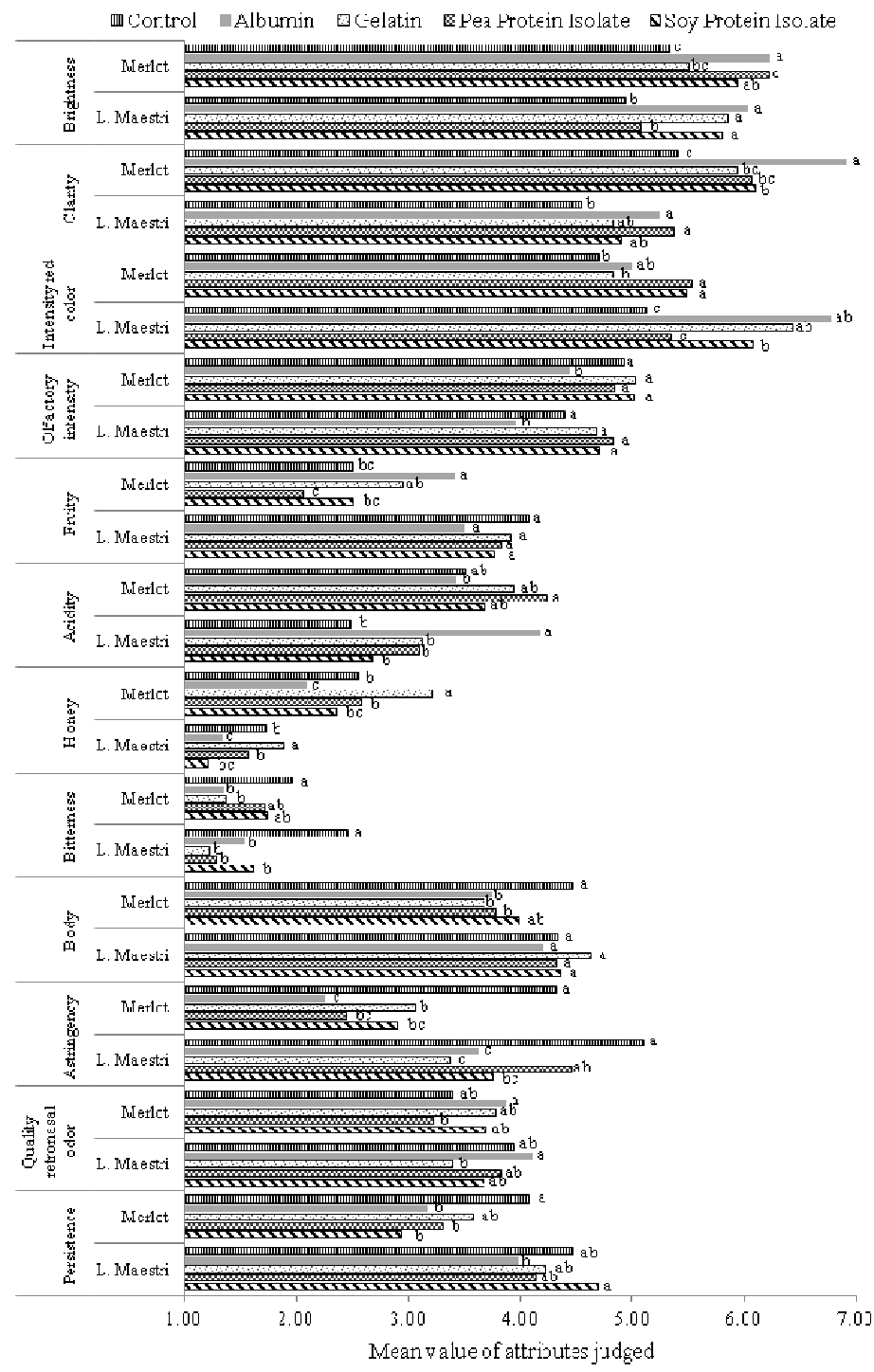

Figure 5. Values found for the studied attributes applied in sensorial evaluation of 'Lambrusco Maestri' and 'Merlot' wines treated with different fining agents (egg albumin, porcine gelatin, pea protein isolate and soy protein isolate). For each fining protein values followed by different letters are significantly different ( $p<0.05$, Tukey's test).

Valores encontrados para os atributos estudados aplicados em avaliação sensorial de vinhos 'Lambrusco Maestri' e 'Merlot' tratados com diferentes colas (albumina de ovo, gelatina de suíno, isolado de proteína de ervilha e isolado de proteina de soja). Para cada clarificante proteico, valores seguidos por letras diferentes são significativamente diferentes ( $p<0.05$, teste de Tukey). 

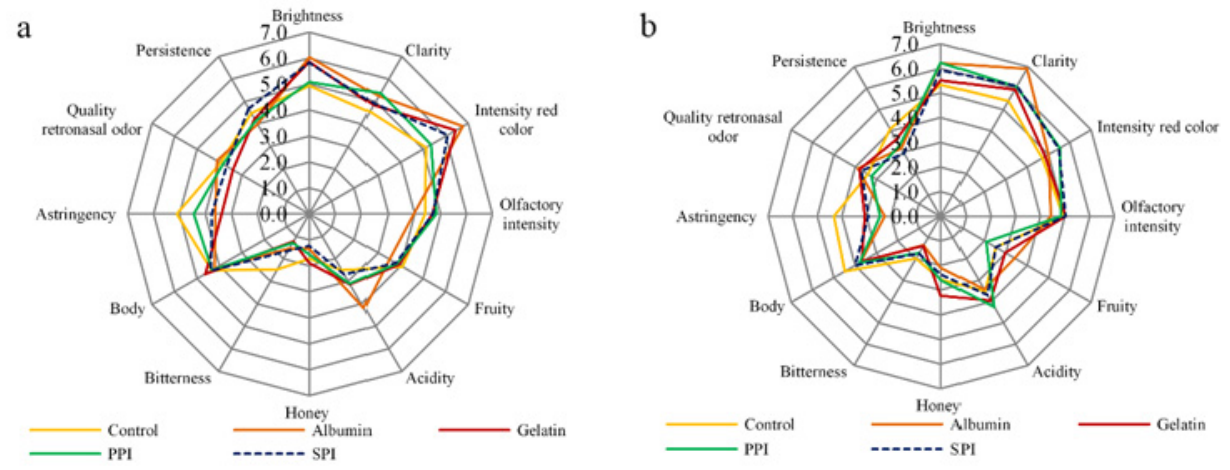

Figure 6. Sensory profiles of red wine obtained by the mean of the scores given by the panellists. Impact of fining on the sensory characteristics of the 'Lambrusco Maestri' (a) and 'Merlot' (b) wines. PPI - pea protein isolate. SPI - soy protein isolate.

Perfis sensoriais dos vinhos tintos obtidos pela média das pontuações dadas pelos painelistas. Impacto da clarificação sobre as características sensoriais dos vinhos 'Lambrusco Maestri' (a) e 'Merlot' (b). PPI-isolado proteico de ervilha. SPI-isolado proteico de soja.

\section{Principal component analysis}

To better evaluate the differences and similarities between the fining treatments, the data were standardized using Principal Component Analysis (PCA). Taken together, the first two principal components (PC1 and PC2) explain $72.67 \%$ of the total variation. The choice of the parameters used was based on the analysis of variance, only the response variables that presented significant $\mathrm{F}$ for the fining agent factor were used in the analysis: turbidity, oligomeric flavan-3-ols, polymeric flavan-3-ols, monomeric flavan-3-ols, total phenolic index, total tannins, total anthocyanins, color intensity, clarity, red color intensity, brightness, olfactory intensity, fruity, body, astringency, bitterness, honey, acidity, quality retronasal odor and persistence.

The two wines used in this study are mainly represented by PC1 (Figure 7), the 'Lambrusco Maestri' wine has positive values, while the 'Merlot' wine has negative values.

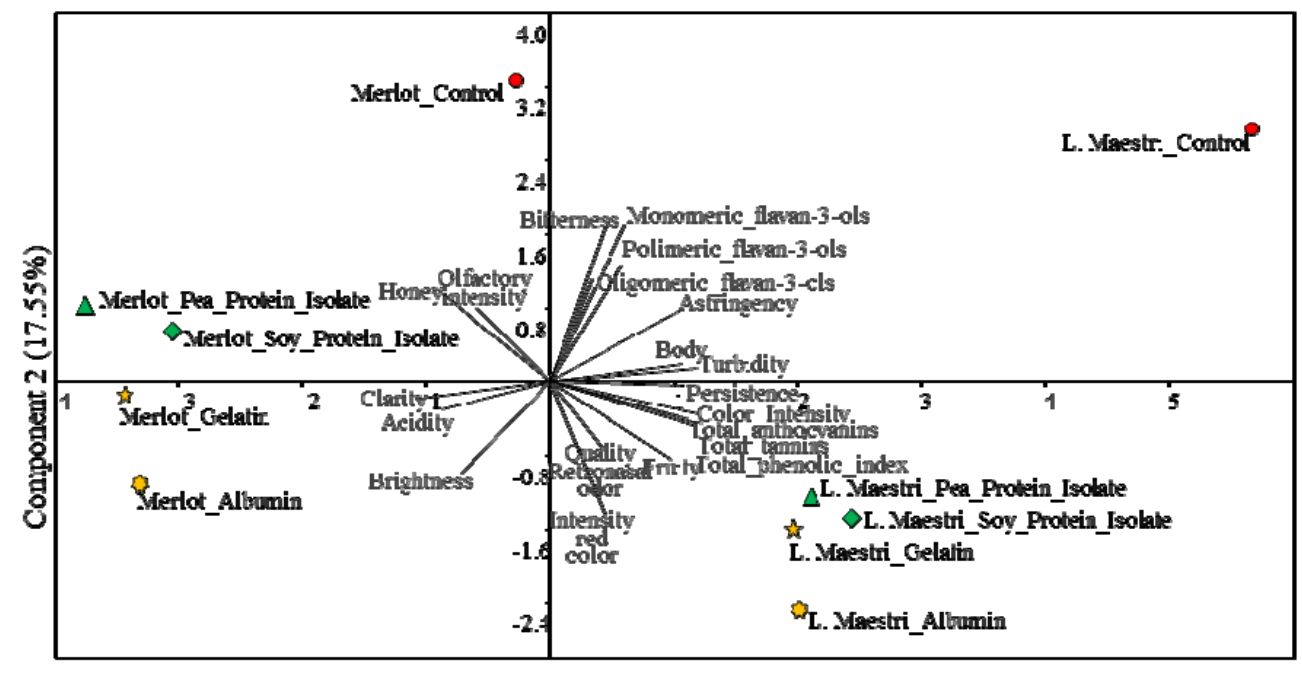

Component $1(55.12 \%)$

Figure 7. PCA representation of wines (control and fined ones) and the physico-chemical and sensory variables in the plane defined by the first two principal components.

Representação PCA de vinhos (controle e clarificados) e as variáveis físico-químicas e sensoriais no plano definido pelos dois primeiros componentes principais. 
The control treatment had larger values in both wines and both components, appearing in the upper right coordinates for the wines subjected to fining. These have lower values (relative to their respective controls) in both $\mathrm{PC} 1$ and $\mathrm{PC}$, illustrating that protein fining, regardless of the protein, promotes a reduction in bitterness, astringency, turbidity, and body, and cause an increase in the clarity, brightness, intensity of the bright red color, and feel of acidity. The animal proteins, especially albumin, promoted, in a comprehensive manner, a considerable change from the original profiles of the wines. Moreover, compared to albumin and gelatin, the SPI had similar behavior, and PPI, promoting less significant changes compared to the control wines. In Figure 7, the results of PCA show that the fining agents have a similar effect in wine. However, the 'Merlot' wine is localized entirely on the left side, and the 'L. Maestri' wine is localized entirely on the right side of the factorial plan. This behavior is an indication that the performance of SPI is similar to other commercial proteins.

\section{CONCLUSIONS}

The results of this study show that SPI is an enological alternative to the current commercial protein fining agents used in red wines. Its application responds similar to ovalbumin, porcine gelatin, and pea protein isolate, both in the physicochemical and sensory aspects. Like other protein agents, SPI reduced the phenolic composition of the two wines studied. The monomeric flavan-3-ols content was decreased, and a less astringency was observed in the two wines. There was a slight reduction in the anthocyanins and the color intensity of the wines with all proteins, including SPI, which was similar to the other results. SPI, like PPI, reduced the turbidity, but the animal proteins promoted a greater reduction. According to the PCA, the fining action of SPI is similar to that of the commercial proteins, especially PPI.

Further studies are necessary to investigate the binding reaction between SPI and the tannins present in wine at a molecular level, determining the most relevant factors that influence the formation of soluble and insoluble complexes.

\section{ACKNOWLEDGEMENTS}

The authors would like to thank IFRS (Instituto Federal de Educação, Ciência e Tecnologia do Rio Grande do Sul), CAPES (Coordenação de Aperfeiçoamento de Pessoal de Nível Superior),
CNPq (Conselho Nacional de Desenvolvimento Científico e Tecnológico) and FAPERGS (Fundação de Amparo à Pesquisa do Estado do Rio Grande do Sul).

\section{REFERENCES}

Aziz M.B., Mouls L., Fulcrand H., Douieb H., Hajjaj H., 2017a. Phenolic compounds of Moroccan red press wines: influence of fining agents and micro-oxygenation treatments. LWT-Food Sci. Tech., 78, 143-150.

Aziz M.B., Mouls L., Fulcrand H., Douieb H., Hajjaj H., 2017b. Micro-oxygenation and fining agent treatments: Impact on color of Moroccan red press wine. J. Food Chem. Nanotechnol., 3, 38-43.

Bindon K.A., Smith P.A., 2013. Comparison of the affinity and selectivity of insoluble fires and commercial proteins for wine proanthocyanidins. Food Chem., 136, 917-928.

Bonerz D.P., Bloomfield D.G., Dykes S.I., Rawel H.M., Rohn S., Kroll J., Creasy G.L., Nikfardjam M.S.P., 2004. A new gentle fining agent for 'Pinot Noir'. Mitteilungen Klosterneuburg, 54, 8695.

Boulton R., 2001. The copigmentation of anthocyanins and its role in the color of red wine: a critical review. Am. J. Enol. Vitic., 52, 67-87.

Bowman S., 2018. The choices and challenges of climate change: options for vineyards to deal with the trend of warmer growing conditions. Aust. N. Z. Grape. Wine., 649, 24-26.

Brossaud F., Cheynier V., Noble A.C., 2001. Bitterness and astringency of grape and wine polyphenols. Aust. J. Grape Wine Res., 7, 33-39.

Cargnello G., 2009. Great chain: urgent necessity the focusing on the metaethical viticulture or great viticulture: research and various considerations. In: 16th International Symposium GiESCO. 31-35. UC Davis, Davis.

Cheynier V., Moutounet M., Sarni-Manchado P., 2000. Los compuestos fenólicos. In: Enología: Fundamentos Científicos y Tecnológicos. 114-136. Gomes A.L. (ed.), Mundi-Prensa, Madrid.

Cosme F., Capão I., Filipe-Ribeiro L., Bennett R.N., Mendes-Faia A., 2012. Evaluating potential alternatives to potassium caseinate for white wine fining: Effects on physicochemical and sensory characteristics. LWT-Food Sci. Tech., 46, 382-387.

Cosme F., Ricardo-da-Silva J.M., Laureano O., 2007. Protein fining agents: characterization and red wine fining assays. Ital. J. Food Sci., 19, 39-56.

Cosme F., Ricardo-da-Silva J.M., Laureano O., 2009. Effect of various proteins on different molecular weight proanthocyanidin fractions of red wine during wine fining. Am. J. Enol Vitic., 60, 7481 .

Dutcosky S.D., 2011. Análise sensorial de alimentos. 426 p. Champagnat, Curitiba.

Gambuti A., Rinaldi A., Moio L., 2012. Use of patatin, a protein extracted from potato, as alternative to animal proteins in fining of red wine. Eur. Food Res. Tech., 235, 753-765.

Gazzola D., Vincenzi S., Marangon M., Pasini G., Curioni A., 2017. Grape seed extract: the first protein-based fining agent endogenous to grapes. Aust. J. Grape Wine Res., 23, 215-225.

Gil-Muñoz R., Gómez-Plaza E., Martınez A., López-Roca J.M., 1999. Evolution of phenolic compounds during wine fermentation 
and post-fermentation: influence of grape temperature. J. Food Comp. Anal., 12, 259-272.

Gómez-Plaza E., Gil-Muñoz R., López-Roca J.M., De La HeraOrts M.L., Martínez-Cultíllas A., 2000. Effect of the addition of bentonite and polyvinylpolypyrrolidone on the colour and longterm stability of red wines. J. Wine Res., 11, 223-231.

González-Neves G., Favre G., Gil G., 2014. Effect of fining on the colour and pigment composition of young red wines. Food Chem., 157, 385-392.

Granato T.M., 2010. Interaction between proteins of plant origin and wine components: molecular-based choice of protein fining agents for organoleptic improvement. 139 p. $\mathrm{PhD}$ Thesis, Università degli Studi di Milano.

Granato T.M., Ferranti P., Iametti S., Bonomi F., 2018. Affinity and selectivity of plant proteins for red wine components relevant to color and aroma traits. Food Chem., 256, 235-243.

Granato T.M., Nasi A., Ferranti P., Iametti S., Bonomi F., 2014. Fining white wine with plant proteins: effects of fining on proanthocyanidins and aroma components. Eur. Food Res. Tech., 238, 265-274.

Granato T.M., Piano F., Nasi A., Ferranti P., Iametti S., Bonomi, F., 2010. Molecular basis of the interaction between proteins of plant origin and proanthocyanidins in a model wine system. $J$. Agric. Food Chem., 58, 11969-11976.

Hammer Ø., Harper D.A., Ryan P.D., 2001. PAST: paleontological statistics software package for education and data analysis. Palaeontol. Electron., 4, 1-9.

Harrison R., 2018. Practical interventions that influence the sensory attributes of red wines related to the phenolic composition of grapes: a review. Int. J. Food Sci. Tech., 53, 3-18.

Hermansson A.M., 1978. Physico-chemical aspects of soy proteins structure formation. J. Texture Stud., 9, 33-58.

Hufnagel J.C., Hofmann T., 2008. Orosensory-directed identification of astringent mouthfeel and bitter-tasting compounds in red wine. J. Agric. Food Chem., 56, 1376-1386.

Instrução Normativa ${ }^{\circ} 24,2005$. Aprova o Manual Operacional de Bebidas e Vinagres. 18 p. Ministério da Agricultura, Pecuária e Abastecimento, Brasília.

Iturmendi N., Durán D., Marín-Arroyo M.R., 2010. Fining of red wines with gluten or yeast extract protein. Int. J. Food Sci. \& Tech., 45, 200-207.

Jackson R.S., 2002. Wine tasting: a professional handbook. 430 p. Academic Press, London.

Jiménez-Martínez M.D., Bautista-Ortín A.B., Gil-Muñoz R. Gómez-Plaza E., 2019. Comparison of fining red wines with purified grape pomace versus commercial fining agents: effect on wine chromatic characteristics and phenolic content. Int. J. Food Sci. \& Tech., 54, 1018-1026.

Jiménez-Martínez M.D., Gómez-Plaza E., Molero N., BautistaOrtín A.B., 2017. Fining of red wines with pomace cell wall material: effect on wine phenolic composition. Food Bioprocess. Tech., 10, 1531-1539.

Kang W., Niimi J., Bastian S.E.P., 2018. Reduction of red wine astringency perception using vegetable protein fining agents. Am. J. Enol. Vitic., 69, 22-31.

Karamanidou A., Kallithraka S., Hatzidimitriou E., 2011. Fining of red wines: effects on their analytical and sensory parameters. J. Int. Sci. Vigne Vin, 45, 47-60.
Kemp S.E., Hollowood T., Hort J., 2009. Sensory evaluation: a practical handbook. 208 p. John Wiley \& Sons, Singapore.

Kinsella J.E., Damodaran S., German B., 1985. Physicochemical and functional properties of oilseed proteins with emphasis on soy proteins. New Protein Foods, 5, 107-179.

Lee C.Y., Jaworski A.W., 1988. Phenolics and browning potential of white grapes grown in New York. Am. J. Enol. Vitic., 39, 337340.

Luck G., Liao H., Murray N.J., Grimmer H.R., Warminski E.E., Williamson M.P., Lilley T.H., Haslam E., 1994. Polyphenols, astringency and proline-rich proteins. Phytochemistry, 37, 357-371.

Machado C.A.E., Mello L.M.R., Guzzo L.C., Zanesco R., Fialho F.B., Hoff R., 2017. Georreferenciamento do cadastro vitícola do Rio Grande do Sul: situação em 2015. In: Cadastro Vitícola do Rio Grande do Sul: 2013 a 2015. 31-51. Mello L.M.R., Machado C.A.E. (eds.), Embrapa Uva e Vinho, Brasília.

Marchal R., Marchal-Delahaut L., Lallement A., Jeandet P., 2002. Wheat gluten used as a clarifying agent of red wines. J. Agric. Food Chem., 50, 177-184.

Maury C., Sarni-Manchado P., Lefebvre S., Cheynier V., Moutounet M., 2001. Influence of fining with different molecular weight gelatins on proanthocyanidin composition and perception of wines. Am. J. Enol. Vitic., 52, 140-145.

Maury C., Sarni-Manchado P., Lefebvre S., Cheynier V., Moutounet M., 2003. Influence of fining with plant proteins on proanthocyanidin composition of red wines. Am. J. Enol. Vitic., 54, 105-111.

Mayén M., Mérida J., Medina M., 1995. Flavonoid and nonflavonoid compounds during fermentation and post-fermentation standing of musts from Cabernet Sauvignon and Tempranillo grapes. Am. J. Enol. Vitic, 46, 255-261.

Noriega-Dominguez M.J., Duran D.S., Virseda P., Marin-Arroyo M.R., 2010. Non-animal proteins as clarifying agents for red wines. J. Int. Sci. Vigne et du Vin, 44, 179-189.

OIV, 2009.Compendium of international methods of wine and must analysis, Vol. 1, 419 p. OIV, Paris.

Oszmianski J., Ramos T., Bourzeix M., 1988. Fractionation of phenolic compounds in red wine. Am. J. Enol. Vitic, 39, 259-262.

Peleg H., Gacon K., Schlich P., Noble A.C., 1999. Bitterness and astringency of flavan-3-ol monomers, dimers and trimers. J. Sci. Food Agric., 79, 1123-1128.

Ribéreau-Gayon P., 1970. Le dosage des composés phénoliques totaux dans les vins rouges. Chim. Anal, 52, 627-631.

Ribéreau-Gayon P., Stonestreet E., 1966. Dosage des tanins du vin rouge et détermination de leur structure. Chim. Anal., 48, 188-207.

Rizzon L.A., Miele.A., 2003. Avaliação da $c v$. Merlot para elaboração de vinho tinto. Ciên. e Tec. de Alim., 23, 156-161.

Robichaud J.L., Noble A.C., 1990. Astringency and bitterness of selected phenolics in wine. J. Sci. Food Agric., 53, 343-353.

Rolland J.M., Apostolou E., Deckert K., de León M.P., Douglass J.A., Glaspole I.N., Bailey M., Stockley C.S., O'Hehir R.E., 2006. Potential food allergens in wine: double-blind, placebo-controlled trial and basophil activation analysis. Nutrition, 22, 882-888.

Sáenz-Navajas M.P., Ferreira V., Dizy M., Fernández-Zurbano P., 2010. Characterization of taste-active fractions in red wine combining HPLC fractionation, sensory analysis and ultraperformance liquid chromatography coupled with mass spectrometry detection. Anal. Chim. Acta, 673, 151-159. 
Sarni-Manchado P. Deleris A., Avallone S. Cheynier V., Moutounet M., 1999. Analysis and characterization of wine condensed tannins precipitated by proteins used as fining agent in enology. Am. J. Enol. Vitic., 50, 81-86.

Simonato B., Mainente F., Selvatico E., Violoni M., Pasini, G., 2013. Assessment of the fining efficiency of zeins extracted from commercial corn gluten and sensory analysis of the treated wine. LWT-Food Sci. Tech., 54, 549-556.

Simonato B., Mainente F., Suglia I., Curioni A., Pasini G., 2009. Evaluation of fining efficiency of corn zeins in red wine: a preliminary study. Ital. J. Food Sci., 21, 97-105.

Sims C.A., Eastridge J.S., Bates R.P., 1995. Changes in phenols, color, and sensory characteristics of muscadine wines by pre-and post-fermentation additions of PVPP, casein, and gelatin. Am. J. Enol. Vitic., 46, 155-158.

Sioumis N., Kallithraka S., Makris D.P., Kefalas P., 2006. Kinetics of browning onset in white wines: influence of principal redoxactive polyphenols and impact on the reducing capacity. Food Chem., 94, 98-104.

Soares S., Brandão E., Mateus N., de Freitas V., 2017. Sensorial properties of red wine polyphenols: astringency and bitterness. Crit. Rev. Food Sci. Nutr., 57, 937-948.

Somers T.C., Evans M.E., 1977. Spectral evaluation of young red wines: anthocyanin equilibria, total phenolics, free and molecular $\mathrm{SO}_{2}$, "chemical age". J. Agric. Food Chem., 28, 279-287.

Sun B., Conceição L., Ricardo D.S.J.M., Spranger I., 1998. Separation of grape and wine proanthocyanidins according to their degree of polymerization. J. Agric. Food Chem., 46, 1390-1396.
Togores J.H., 2018. Tratado de Enologia. $3^{\text {rd }}$ Edition. 1936 p. Mundi-Prensa Libros, Madrid.

Tschiersch C., Nikfardjam M.P., Schmidt O., Schwack W., 2010. Degree of hydrolysis of some vegetal proteins used as fining agents and its influence on polyphenol removal from red wine. Eur. Food Res. Tech., 231, 65-74.

Vernhet A., 2019. Red Wine Clarification and Stabilization. In: Red Wine Technology. 237-251. Morata A. (ed.), Academic Press, London.

Vincenzi S., Dinnella C., Recchia A., Monteleone E., Gazzola D. Pasini G., Curioni A., 2013. Grape seed proteins: a new fining agent for astringency reduction in red wine. Austr. J. Grape Wine Res., 19, 153-160.

Wally-Vallim A.P., Vanier N.L., Zavareze E.D.R., Zambiazi R.C., de Castro L.A.S., Schirmer M.A., Elias M.C., 2014. Isoflavone aglycone content and the thermal, functional, and structural properties of soy protein isolates prepared from hydrothermally treated soybeans. J. Food Sci., 79, E1351-E1358.

Yokotsuka K., Singleton V.L., 1995. Interactive precipitation between phenolic fractions and peptides in wine-like model solutions: turbidity, particle size, and residual content as influenced by $\mathrm{pH}$, temperature and peptide concentration. Am. J. Enol. Vitic., 46, 329-338.

Zamora F., 2003. Elaboración y crianza del vino tinto: aspectos científicos y prácticos. 225 p. Mundiprensa, Madrid. 